\title{
Processes controlling the concentration of hydroperoxides at Jungfraujoch Observatory, Switzerland
}

\author{
S. J. Walker ${ }^{1}$, M. J. Evans ${ }^{1}$, A. V. Jackson ${ }^{1}$, M. Steinbacher ${ }^{2}$, C. Zellweger ${ }^{2}$, and J. B. McQuaid ${ }^{1}$ \\ ${ }^{1}$ Institute for Atmospheric Science, School of the Earth and Environment, University of Leeds, Leeds, UK \\ ${ }^{2}$ Swiss Federal Institute for Materials Science and Technology (Empa), Laboratory for Air Pollution/Environmental \\ Technology, 8600 Dübendorf, Switzerland
}

Received: 6 June 2006 - Published in Atmos. Chem. Phys. Discuss.: 28 July 2006

Revised: 17 October 2006 - Accepted: 30 November 2006 - Published: 7 December 2006

\begin{abstract}
An automated, ground-based instrument was used to measure gas-phase hydroperoxides at the Jungfraujoch High Altitude Research Station as part of the Free Tropospheric EXperiment (FREETEX) during February/March 2003. A nebulising reflux concentrator sampled ambient air twice hourly, prior to on-site analysis by HPLC speciation, coupled with post-column peroxidase derivatisation and fluorescence detection. Hydrogen peroxide $\left(\mathrm{H}_{2} \mathrm{O}_{2}\right)$ concentrations reached up to $1330 \mathrm{pptv}$ over the 13-day period with a mean of $183 \pm 233 \mathrm{pptv}$ ( \pm one standard deviation). Methyl hydroperoxide $\left(\mathrm{CH}_{3} \mathrm{OOH}\right)$ reached up to $379 \mathrm{pptv}$ with a mean of $51 \pm 55$ pptv. No other organic hydroperoxides were detected. The lack of an explicit diurnal cycle suggests that hydroperoxide concentrations are chiefly influenced by transport processes rather than local photochemistry at this mountainous site. There was some evidence that elevated concentrations of $\mathrm{H}_{2} \mathrm{O}_{2}$ existed in air-masses originating from the south-west, suggesting higher concentrations of $\mathrm{HO}_{\mathrm{x}}$ due to more active photochemistry. Air which had been recently polluted exhibited low $\mathrm{H}_{2} \mathrm{O}_{2}$ concentration due to a combination of suppression of $\mathrm{HO}_{2}$ by $\mathrm{NO}_{\mathrm{x}}$ and deposition. The concentrations of $\mathrm{H}_{2} \mathrm{O}_{2}$ sampled here are consistent with previous box modelling studies of hydroperoxides, except in periods influenced by the boundary layer, where agreement required a depositional sink.
\end{abstract}

\section{Introduction}

Hydroperoxides play an important role in gas-phase free radical chemistry of the atmosphere and in the aqueousphase chemistry of acid precipitation. Hydroperoxides such as hydrogen peroxide $\left(\mathrm{H}_{2} \mathrm{O}_{2}\right)$ and methyl hydroperoxide $\left(\mathrm{CH}_{3} \mathrm{OOH}\right)$ are produced through the self-reaction of per-

Correspondence to: A. V. Jackson

(andrea@env.leeds.ac.uk) oxy radicals (hydroperoxy, $\mathrm{HO}_{2}$ and organic peroxy, $\mathrm{RO}_{2}$ ) (e.g. Lee et al., 2000). These peroxy radicals are intimately linked to ozone $\left(\mathrm{O}_{3}\right)$ production and loss, leading to hydroperoxides being a key diagnostic of the chemical state of the atmosphere. The chemistry of odd oxygen species $\left(\mathrm{O}_{\mathrm{x}}\right)$, $\mathrm{HO}_{\mathrm{x}}$ (the hydroxyl radical, $\mathrm{OH}$ and $\mathrm{HO}_{2}$ ) and $\mathrm{RO}_{\mathrm{x}}(\mathrm{RO}$ and $\mathrm{RO}_{2}$ ) is summarized in Fig. $1 . \mathrm{H}_{2} \mathrm{O}_{2}$ is also a major oxidant of sulphur dioxide $\left(\mathrm{SO}_{2}\right)$ in clouds (Penkett et al., 1979) so alongside $\mathrm{O}_{3}$ and $\mathrm{OH}$, its measurement is needed to assess the oxidative capacity of the atmosphere.

Previous analyses of $\mathrm{H}_{2} \mathrm{O}_{2}$ and $\mathrm{CH}_{3} \mathrm{OOH}$ observations have identified key physical and chemical processes controlling their concentration (e.g. Heikes et al., 1987). As shown in Fig. 1, the production of $\mathrm{H}_{2} \mathrm{O}_{2}$ is controlled by the abundance of $\mathrm{HO}_{2}$, which shows sensitivity to $\mathrm{HO}_{x}$ production, loss and recycling. Formation of peroxy radicals is predominantly through the photo-oxidation of carbon monoxide (CO) and volatile organic compounds (VOC), by the $\mathrm{OH}$ radical (detailed in Lightfoot et al., 1992). A second significant source is from formaldehyde $\left(\mathrm{CH}_{2} \mathrm{O}\right)$, which undergoes photolysis and reaction with $\mathrm{OH}$ to produce $\mathrm{HO}_{2}$.

Air-masses rich in nitrogen oxides, $\mathrm{NO}_{\mathrm{x}}\left(\mathrm{NO}\right.$ and $\left.\mathrm{NO}_{2}\right)$ tend to show lower $\mathrm{H}_{2} \mathrm{O}_{2}$ concentrations as peroxy radicals oxidise $\mathrm{NO}$ to $\mathrm{NO}_{2}$ rather than self-reacting to form $\mathrm{H}_{2} \mathrm{O}_{2}$ (Tremmel et al., 1993; Penkett et al., 1995) and total radical loadings are suppressed by nitric acid $\left(\mathrm{HNO}_{3}\right)$ production through the reaction of $\mathrm{OH}$ with $\mathrm{NO}_{2}$ radicals (Poppe et al., 1993). According to Lee et al. (2000), substantial suppression of hydroperoxide production occurs at NO concentrations exceeding $100 \mathrm{pptv}$. It is calculated that NO concentrations below 3 to $20 \mathrm{pptv}$ are needed for hydroperoxide production to dominate over the reaction between $\mathrm{HO}_{2}$ and NO (Reeves and Penkett, 2003; Crutzen and Zimmermann, 1991; Finlayson-Pitts and Pitts, 1986). Such low concentrations of NO can only be found in very remote regions of the troposphere lacking $\mathrm{NO}_{\mathrm{x}}$ sources. 


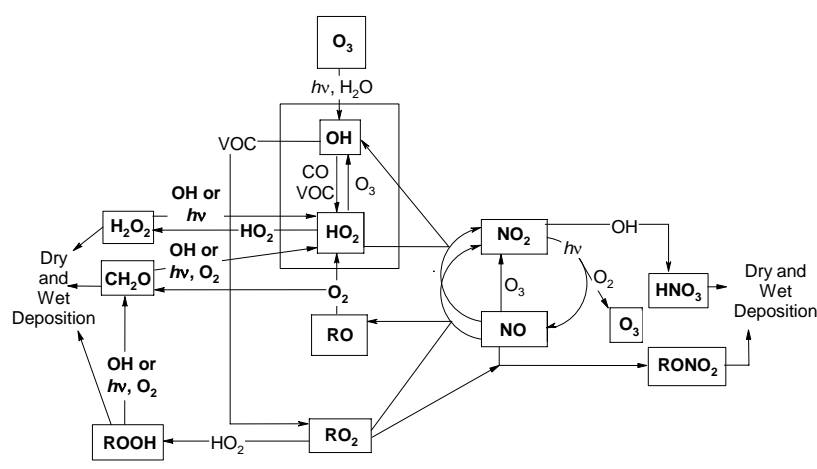

Fig. 1. Tropospheric gas-phase reactions linked to hydroperoxides.

Lower concentrations of $\mathrm{H}_{2} \mathrm{O}_{2}$ are observed in air-masses exposed to the ground or clouds due to dry and wet deposition (e.g. Kleinman, 1986; Heikes et al., 1987; Chandler et al., 1988; Gallagher et al., 1991). Rapid loss of gaseous $\mathrm{H}_{2} \mathrm{O}_{2}$ into clouds is due to a high Henry's law coefficient of $\mathrm{H}_{2} \mathrm{O}_{2}\left(\mathrm{H}_{\mathrm{H}_{2} \mathrm{O}_{2}}\right.$ is $7.73 \times 10^{4} \mathrm{M}$ atm ${ }^{-1}$ at $298 \mathrm{~K}$, Sander et al., 2003) and rapid oxidation of $\mathrm{S}(\mathrm{IV})$ species to $\mathrm{S}(\mathrm{VI})$ within the aqueous phase. Other important $\mathrm{H}_{2} \mathrm{O}_{2}$ and $\mathrm{CH}_{3} \mathrm{OOH}$ sinks are their reaction with $\mathrm{OH}$ radicals and photolysis at ultraviolet wavelengths.

The aim of this paper is to investigate the impact of these chemical and physical processes on the concentration of $\mathrm{H}_{2} \mathrm{O}_{2}$ and $\mathrm{CH}_{3} \mathrm{OOH}$ at a remote mountainous site and to understand the usefulness of $\mathrm{H}_{2} \mathrm{O}_{2}$ observations as a diagnostic of the atmospheric compositional system.

\section{Experimental}

\subsection{Site description}

The observations are from the FREE Tropospheric EXperiment (FREETEX) that took place in February to March 2003 at the Sphinx Observatory, Jungfraujoch High Altitude Research Station $\left(7.98^{\circ}\right.$ E, $\left.46.55^{\circ} \mathrm{N}\right)$ (subsequently referred to as JFJ) situated at $3580 \mathrm{~m}$ above mean sea level (a.m.s.l.). There have been three previous FREETEX campaigns in 1996, 1998 and 2001 at this site (Zanis et al., 1999, 2000a, b, 2003; Carpenter et al., 2000). The Sphinx Observatory resides in a saddle between the two alpine summits, Jungfrau (4155 m a.m.s.l.) to the south-west and Mönch (4099 m a.m.s.1.) to the north-east, in the Swiss Alps. This leads to mainly north-westerly and southerly air-masses reaching the station (see Fig. 2). The site characteristics are described in Zellweger et al. (2003). The observatory is usually thought to be located in the lower free troposphere (FT) in winter and early spring but can experience planetary boundary layer (PBL) air (Carpenter et al., 2000), especially in the summer when convection is enhanced (Baltensperger et al., 1997; Lugauer et al., 1998, Zellweger et al.,
2003). The high altitude site is thought to experience few local emission sources, and therefore can offer ideal conditions for long-term sampling of free tropospheric air. The JFJ is incorporated in the Swiss National Air Pollution Monitoring Network (NABEL), which is maintained by EMPA Dübendorf on behalf of the Swiss Federal Office for the Environment (FOEN). Among other species, $\mathrm{NO}, \mathrm{NO}_{2}, \mathrm{O}_{3}$ and $\mathrm{CO}$ are measured routinely and are available with a time resolution of $30 \mathrm{~min}$. All meteorological parameters are measured by the Federal Office of Meteorology and Climatology (MeteoSwiss). Due to the importance of monitoring long-term trends of gaseous and aerosol parameters in the free troposphere, the JFJ station has been incorporated into the Global Atmosphere Watch (GAW) program of the World Meteorological Organization (WMO) as a Global GAW Station.

2.2 Method for hydroperoxide sample collection and analysis

Sample collection took place at the Sphinx laboratory between the 27 February and the 12 March 2003. Figure 3 shows a schematic diagram of the analytical system. Samples were obtained from the gas-phase using an amber-glass nebulising reflux concentrator (Fig. 3) based on the design by Cofer et al. (1985). Atmospheric air was drawn by a vacuum pump from the NABEL inlet (previously described in Zellweger et al., 2000), through $\sim 5 \mathrm{~m} \frac{1}{4}^{\prime \prime}$ OD Teflon (perfluoroalkoxy) tubing into the nebuliser, at a flow rate of $2.71 \mathrm{~min}^{-1}$. The residence time in the inlet tubing was less than $4 \mathrm{sec}$. A sampling time of $25 \mathrm{~min}$ provided sufficient concentration of the solution for analysis. Collection efficiencies of $75 \pm 3 \%$ and $40 \pm 2 \%$ have been previously determined experimentally for $\mathrm{H}_{2} \mathrm{O}_{2}$ and $\mathrm{CH}_{3} \mathrm{OOH}$ respectively and were assumed in this study (Jackson and Hewitt, 1996; Morgan, 2004).

Once collected, aqueous samples were injected through a $0.2 \mu \mathrm{m}$ filter onto the HPLC where hydroperoxide speciation was achieved using a C-18 reversed-phase column. Helium-degassed mobile phase was supplied at a flow rate of $0.6 \mathrm{ml} \mathrm{min}^{-1}$. Post-column, the hydroperoxide components were derivatised in a reaction coil in the presence of horseradish peroxidase to form a stable dimer, based on the technique developed by Lazrus et al. $(1985,1986)$. The derivatisation reagent was raised to $\mathrm{pH} 5.8$ by the addition of potassium hydroxide $(1 \mathrm{M})$ and buffered by potassium hydrogen phthalate $(0.5 \mathrm{M})$. A peristaltic pump delivered the derivatisation reagent at constant rate of $0.25 \mathrm{ml} \mathrm{min}^{-1}$. The $\mathrm{pH}$ was then raised above 10 to produce the fluorescent anionic dimer form via a Nafion membrane submerged in $100 \mathrm{ml}$ ammonium hydroxide (30\%). Detection was achieved using a fluorescence spectrophotometer with excitation and emission wavelengths of 305 and $410 \mathrm{~nm}$ respectively, via a xenon short arc lamp. Calibration of the system was carried out daily. Further details of this method 


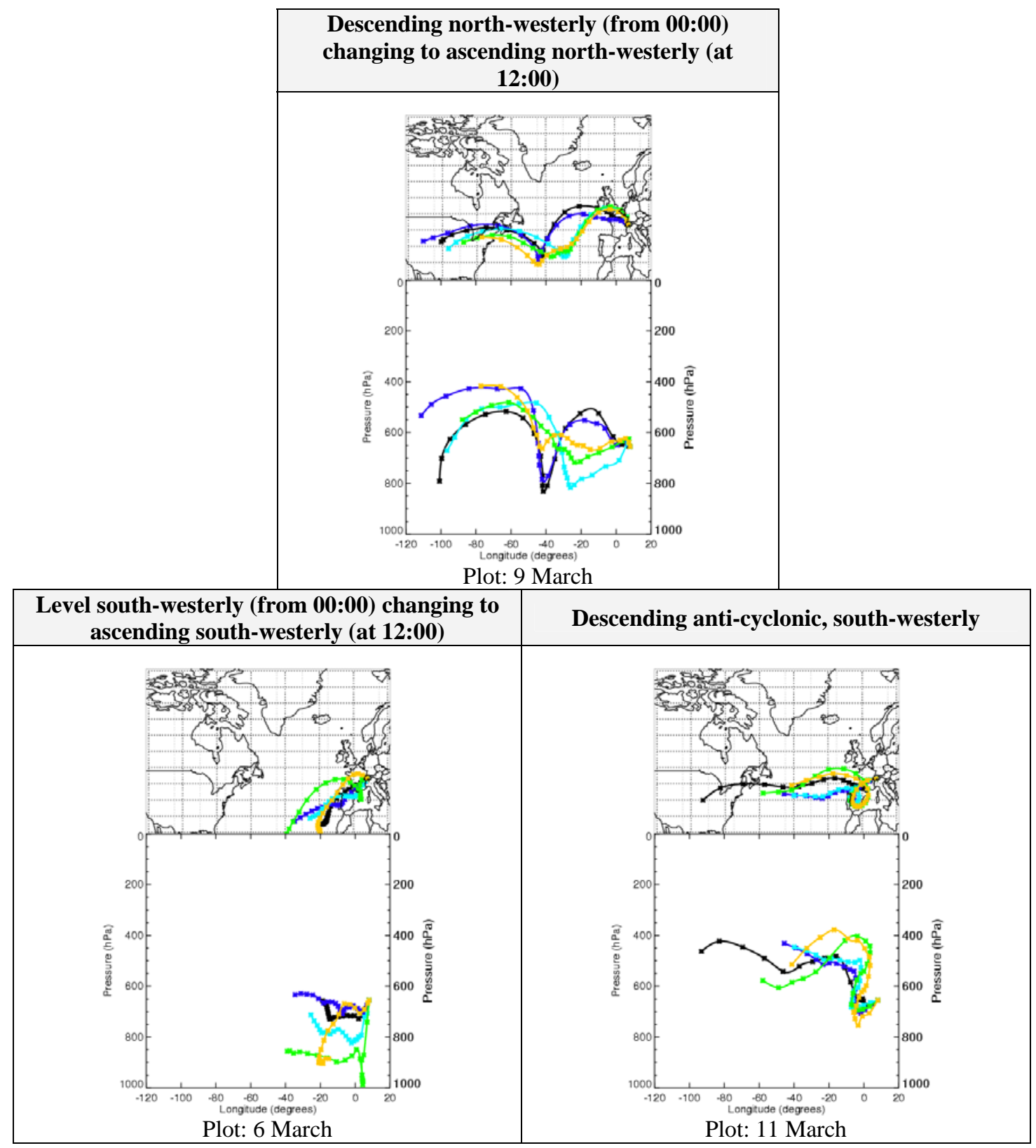

Fig. 2. Typical 5-day back-trajectories of air-masses sampled at JFJ (provided by the BADC Trajectory Server). Arrival dates of trajectories are shown. Trajectory release times are 00:00 (black), 06:00 (dark blue), 12:00 (light blue), 18:00 (green) and 24:00 (orange) in GMT. Crosses are every $6 \mathrm{~h}$ along trajectory.

can be found in Morgan and Jackson (2002). Based on three and ten times the standard deviation of the base line noise, the instrument limit of detection and quantification at $95 \%$ confidence (Taylor, 1987) during the campaign was found to be 24 and 81 pptv respectively.

\subsection{Other measurements}

An overview of measurement techniques including detection limits and uncertainties of $\mathrm{O}_{3}, \mathrm{CO}, \mathrm{NO}_{\mathrm{x}}$ and reactive nitrogen species, $\mathrm{NO}_{\mathrm{y}}\left(\mathrm{NO}_{\mathrm{x}}\right.$ and all other species resulting from the atmospheric oxidation of $\mathrm{NO}_{\mathrm{x}}$ ) can be found in Zellweger et al. (2000) and for toluene and benzene in Reimann et al. (2004). A further suite of species, namely non-methane hydrocarbons (NMHCs), $\mathrm{CO}, \mathrm{O}_{3}$, PAN (perox- 


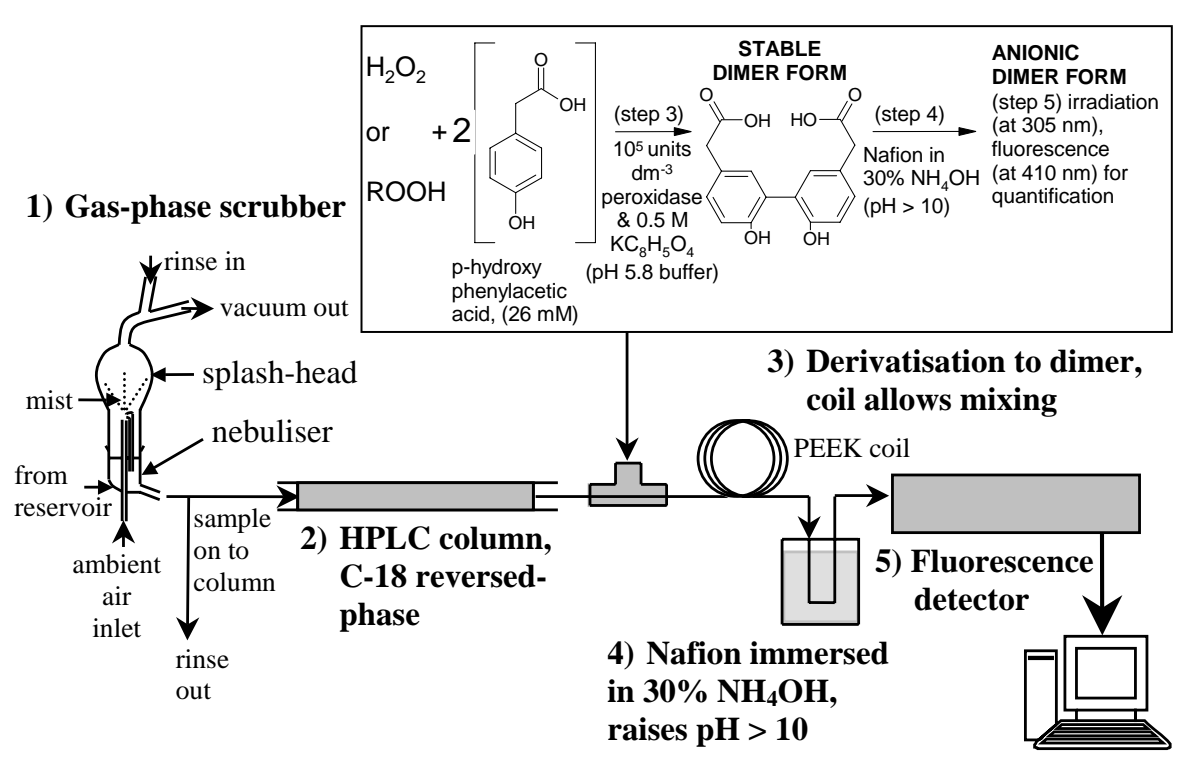

Fig. 3. Schematic diagram of gas-phase sampling and analysis of hydroperoxides using a nebulising reflux concentrator, HPLC and postcolumn derivatisation.

yacetyl nitrate) and the photolysis rate coefficient, $j\left(\mathrm{O}^{1} D\right)$, were measured throughout the campaign by the University of Leeds (School of Chemistry) and are described in Whalley et al. (2004).

\section{Results and discussion}

\subsection{General observations}

Figure 4 presents the 13-day time series for $\mathrm{H}_{2} \mathrm{O}_{2}$ and $\mathrm{CH}_{3} \mathrm{OOH}$ for the sampling period. $\mathrm{H}_{2} \mathrm{O}_{2}$ ranged from below the limit of detection (24 pptv) up to $1330 \mathrm{pptv}$ with an average concentration of $183 \pm 233$ pptv ( \pm one standard deviation). Table 1 presents this data alongside previous measurements at other high altitude sites and from aircraft. The observations made during this campaign are consistent with previous measurements. More specifically they are within the range of previous $\mathrm{H}_{2} \mathrm{O}_{2}$ measurements at this site and other Alpine sites ( $<100-6000$ pptv) (Dommen et al., 1995; Sigg et al., 1992; Lehman et al., 1992). However, the observed mean for $\mathrm{H}_{2} \mathrm{O}_{2}$ appears lower than those previously observed at alpine sites. This may be because the previous measurements were made during the summer, included forested areas (where hydroperoxides can be produced through biogenic hydrocarbon oxidation), and also excluded periods of cloud or rain (so concentrations were not reduced through wet deposition). Although direct comparison between these datasets is difficult we conclude that our observational dataset appear consistent with previous observations.

$\mathrm{CH}_{3} \mathrm{OOH}$ was observed during this campaign and ranged from below the detection limit, up to 379 pptv, with a mean mixing ratio of $51 \pm 55 \mathrm{pptv}$. There are no previously published $\mathrm{CH}_{3} \mathrm{OOH}$ measurements for this site. Again these observations are consistent with previous observations at other sites (see Table 1). No other higher hydroperoxides were detected. This will be discussed in more detail in Sect. 3.7.

\subsection{Effect of local and synoptic scale meteorology}

Mean diurnal cycles for $\mathrm{H}_{2} \mathrm{O}_{2}$ and $\mathrm{CH}_{3} \mathrm{OOH}$ are shown in Fig. 5. There is some suggestion of a maximum in hydroperoxide concentrations during the day indicative of photochemical production (e.g. Dommen et al., 1995). However, there is significant variability, suggesting a large role for meteorology in determining the levels of hydroperoxides sampled.

Four hydroperoxide maxima were observed on the 1,6 , 9 and 11 March. The mean vector-averaged local wind direction ( \pm 1 standard deviation) throughout the campaign was north-westerly $\left(312 \pm 68^{\circ}\right)$ with no consistent change in the local wind direction during the hydroperoxide maxima. Since the local wind direction is influenced by local orography due to the location of the sampling site in a mountain saddle, the local wind direction appears to offer little information on the magnitude of the hydroperoxide concentration.

Back trajectories were calculated each $6 \mathrm{~h}$ of the campaign using ECMWF analysed winds at $2.5 \times 2.5^{\circ}$ resolution and 31 levels using 3-D vertical advection via the BADC Trajectory Service (http://badc.nerc.ac.uk). These trajectories agreed well with plots calculated using the FLEXTRA Trajectory Service (http://zardoz.nilu.no/ andreas/flextra+flexpart. $\mathrm{html})$, which offers a finer resolution $\left(1.125 \times 1.125^{\circ}\right)$ appropriate for the Alpine region. The "synoptic wind direction" (diagnosed from the last day of transport described by the tra- 
Table 1. Selected hydroperoxide measurements at high altitude.

\begin{tabular}{|c|c|c|c|c|c|}
\hline $\begin{array}{l}\text { Altitude } \\
\text { (km a.m.s.1.) }\end{array}$ & Location & Time of year & $\begin{array}{l}\text { Mean } \mathrm{H}_{2} \mathrm{O}_{2} \\
\text { (pptv, } \\
\text { range) }\end{array}$ & $\begin{array}{l}\text { Mean } \mathrm{CH}_{3} \mathrm{OOH} \\
\text { (pptv, } \\
\text { range) }\end{array}$ & Notes \\
\hline \multicolumn{6}{|c|}{ High Altitude Sites } \\
\hline 3.6 & $\begin{array}{l}\text { Jungfraujoch, } \\
\text { Swiss Alps } \\
\left(47^{\circ} \mathrm{N}, 8^{\circ} \mathrm{E}\right)\end{array}$ & Feb-March 2003 & $\begin{array}{l}183 \pm 233 \\
(<24-1330)\end{array}$ & $\begin{array}{l}51 \pm 55 \\
(<24-379)\end{array}$ & This work, no significant diurnal cycle \\
\hline $0.5-5.0$ & $\begin{array}{l}\text { Ground and } \\
\text { Airborne, Swiss } \\
\text { Plateau/Alps (incl. } \\
\text { JFJ, } 47^{\circ} \mathrm{N}, 8^{\circ} \mathrm{E} \text { ) }\end{array}$ & $\begin{array}{l}\text { June-July } 1990 \\
\text { July-Aug } 1991\end{array}$ & $\begin{array}{l}\sim 1400 \text { for JFJ excl. } \\
\text { rain/cloud events } \\
(<100-6000)\end{array}$ & $\begin{array}{l}\text { Not measured } \\
(\mathrm{ROOH}<300)\end{array}$ & $\begin{array}{l}\text { No distinct diurnal cycle, airborne sam- } \\
\text { pling via manned balloon/glider (Dom- } \\
\text { men et al., 1995; Sigg et al., 1992; and } \\
\text { Lehman et al., 1992) }\end{array}$ \\
\hline $1.2-1.8$ & $\begin{array}{l}\text { Ground, Bavarian } \\
\text { Alps, Germany } \\
\left(47^{\circ} \mathrm{N}, 11^{\circ} \mathrm{E}\right)\end{array}$ & June-Sep 1990 & $\sim 750(<50-1750)$ & $\sim 100(<20-550)$ & $\begin{array}{l}\text { Diurnal variation, } \mathrm{HOCH}_{2} \mathrm{OOH} \\
<550 \text { pptv, also detected } \\
\mathrm{C}_{2} \mathrm{H}_{5} \mathrm{OOH} \text { and } \mathrm{CH}_{3} \mathrm{C}(\mathrm{O}) \mathrm{OOH} \text {, total } \\
\text { ROOH was } 10-40 \% \mathrm{H}_{2} \mathrm{O}_{2} \text { (Fels and } \\
\text { Junkermann, 1994) }\end{array}$ \\
\hline 2.8 & $\begin{array}{l}\text { Mt. Norikura, central } \\
\text { Japan }\left(37^{\circ} \mathrm{N},\right. \\
\left.137^{\circ} \mathrm{E}\right)\end{array}$ & $\begin{array}{l}\text { July-Sep 1993, } \\
1994\end{array}$ & $\begin{array}{l}1100 \pm 750 \text { for August } \\
(100-4500)\end{array}$ & $\begin{array}{l}\text { Not measured } \\
(\mathrm{ROOH}<1000, \\
\text { Semi-quantitative })\end{array}$ & $\begin{array}{l}\text { Peak } \mathrm{H}_{2} \mathrm{O}_{2} \text { at night (Watanabe et al., } \\
\text { 1995) }\end{array}$ \\
\hline \multicolumn{6}{|l|}{ Airborne } \\
\hline $0.3-13$ & $\begin{array}{l}\text { North Pacific } \\
\text { Ocean }\left(0-65^{\circ} \mathrm{N}\right. \\
\left.115^{\circ} \mathrm{E}-125^{\circ} \mathrm{W}\right)\end{array}$ & Autumn 1991 & $\begin{array}{l}<1000 \\
\left(\text { for }>45^{\circ} \mathrm{N}\right) \\
(<30-6000)\end{array}$ & $\begin{array}{l}<500 \\
\left(\text { for }>45^{\circ} \mathrm{N}\right) \\
(<50-3000)\end{array}$ & $\begin{array}{l}\text { Other ROOHs not detected } \\
(<100 \text { pptv) (Heikes et al., } \\
\text { 1996a) }\end{array}$ \\
\hline $0.3-10$ & $\begin{array}{l}\text { South Atlantic and } \\
\text { W. Indian Oceans } \\
\left(20^{\circ} \mathrm{N}-40^{\circ} \mathrm{S} \text {, }\right. \\
\left.60^{\circ} \mathrm{W}-40^{\circ} \mathrm{E}\right)\end{array}$ & Sep-Oct 1992 & $\begin{array}{l}3200 \pm 1800 \text { (for } \\
\text { MBL to } 4 \mathrm{~km}) \\
(300-6000)\end{array}$ & $\begin{array}{l}1000 \pm 450 \\
(400-1900)\end{array}$ & $\begin{array}{l}\text { Vertical } \mathrm{H}_{2} \mathrm{O}_{2} \text { profiles (Heikes et al., } \\
1996 \mathrm{~b} \text { ) }\end{array}$ \\
\hline $0-12$ & $\begin{array}{l}\text { Tropical South } \\
\text { Pacific }\left(0-30^{\circ} \mathrm{S},\right. \\
\left.170^{\circ} \mathrm{E}-110^{\circ} \mathrm{W}\right)\end{array}$ & Sep-Oct 1996 & $200 \pm 110(0-1600)$ & $80 \pm 80(0-1200)$ & $\begin{array}{l}\text { Vertical } \mathrm{H}_{2} \mathrm{O}_{2} \text { profiles, for } \\
3.5 \mathrm{~km}, \mathrm{H}_{2} \mathrm{O}_{2} \text { and } \mathrm{CH}_{3} \mathrm{OOH} \\
\sim 1100 \text { and } \sim 500 \text { pptv (Cohan et } \\
\text { al., 1999) }\end{array}$ \\
\hline 10 & $\begin{array}{l}\text { Tropical South Pacific } \\
\left(13^{\circ} \mathrm{S}, 152^{\circ} \mathrm{E}\right)\end{array}$ & April 1999 & $77 \pm 21(50-120)$ & $64 \pm 24(50-500)$ & (Ravetta et al., 2001) \\
\hline $0.5-3.0$ & $\begin{array}{l}\text { Nashville, } \\
\text { Tennessee } \\
\left(36^{\circ} \mathrm{N}, 87^{\circ} \mathrm{W}\right)\end{array}$ & July 1995 & $\begin{array}{l}2400(\text { median }) \\
(<100-5000)\end{array}$ & $\begin{array}{l}1700 \text { (median) } \\
(500-3750)\end{array}$ & $\begin{array}{l}\text { Assumed only } \mathrm{H}_{2} \mathrm{O}_{2}, \mathrm{CH}_{3} \mathrm{OOH} \\
\text { and } \mathrm{HOCH}_{2} \mathrm{OOH} \text { (also } \\
\text { detected) were collected } \\
\text { (Weinstein-Lloyd et al., 1998) }\end{array}$ \\
\hline $0.7-3.7$ & $\begin{array}{l}\text { Central Arkansas } \\
\left(35^{\circ} \mathrm{N}, 92^{\circ} \mathrm{W}\right)\end{array}$ & Jan-Oct 1988 & $\begin{array}{l}\sim 200 \text { winter mean } \\
(<10-8000)\end{array}$ & Not measured & (Ray et al., 1992) \\
\hline $0-3.5$ & $\begin{array}{l}\text { Eastern U.S. } \\
\left(25-44^{\circ} \mathrm{N}\right. \\
\left.76-89^{\circ} \mathrm{W}\right)\end{array}$ & Oct-Nov 1984 & $\begin{array}{l}400-1900 \\
(<200-4100)\end{array}$ & $\begin{array}{l}\text { Not quantitative } \\
(\mathrm{ROOH}<500)\end{array}$ & $\begin{array}{l}\text { Vertical } \mathrm{H}_{2} \mathrm{O}_{2} \text { profiles (Heikes et al., } \\
\text { 1987). }\end{array}$ \\
\hline
\end{tabular}

jectory) was in general from the west/north-west for $\sim 55 \%$ of the campaign (consistent with the observed wind direction) except in periods during the 28 February to 2 March, 5 to 6 and 10 to 12 March when air-masses with a southwesterly character were sampled (see Fig. 2 for examples of these trajectories). Three of the four hydroperoxide maxima occurred on the arrival of these synoptic south-westerly airmasses (1, 6 and 11 March). The maxima observed on the 9 March was during a period of north-westerly air (see Fig. 2), and is discussed separately in Sect. 3.4.

During south-westerly flow, primary photochemical pollutants e.g. $\mathrm{CO}$ and $\mathrm{NO}_{\mathrm{x}}$, were sometimes enhanced, as illustrated in Whalley et al. (2004) for this campaign and previously seen in past campaigns at this site (Forrer et al., 2000; Carpenter et al., 2000). As described earlier, the relationship between hydroperoxides and primary pollutants (notably $\mathrm{NO}_{\mathrm{x}}$ ) is complicated. Hydroperoxide concentra- tions were sensitive to the $\mathrm{NO}_{\mathrm{x}}$ concentration within these air-masses. High hydroperoxide concentrations were only present when $\mathrm{NO}_{\mathrm{x}}$ concentrations were low. The correlation coefficient between $\mathrm{H}_{2} \mathrm{O}_{2}$ or $\mathrm{CH}_{3} \mathrm{OOH}$ concentrations and $j\left(\mathrm{O}^{1} D\right)$ for 10:00 to 14:00 each day during the campaign gave a $\mathrm{R}^{2}$ of $<0.05$ which indicates that the concentrations of hydroperoxide are not determined by their photochemical production. The south-westerly air-mass sampled during 11 March was also photochemically aged based on the distinction of Chin et al. (1994), who used a $\mathrm{NO}_{\mathrm{x}} / \mathrm{NO}_{\mathrm{y}}$ ratio of $<0.3$ to evaluate when an air-mass could be described as photochemically aged. Air-masses with ratios significantly above this can therefore be classed as recently polluted. Secondly, the toluene/ benzene ratio was also used to support this classification, where values below 0.5 were indicative of aged air-masses due to the shorter atmospheric lifetime of toluene compared to benzene ( $\mathrm{Li}$ et al., 2006). 

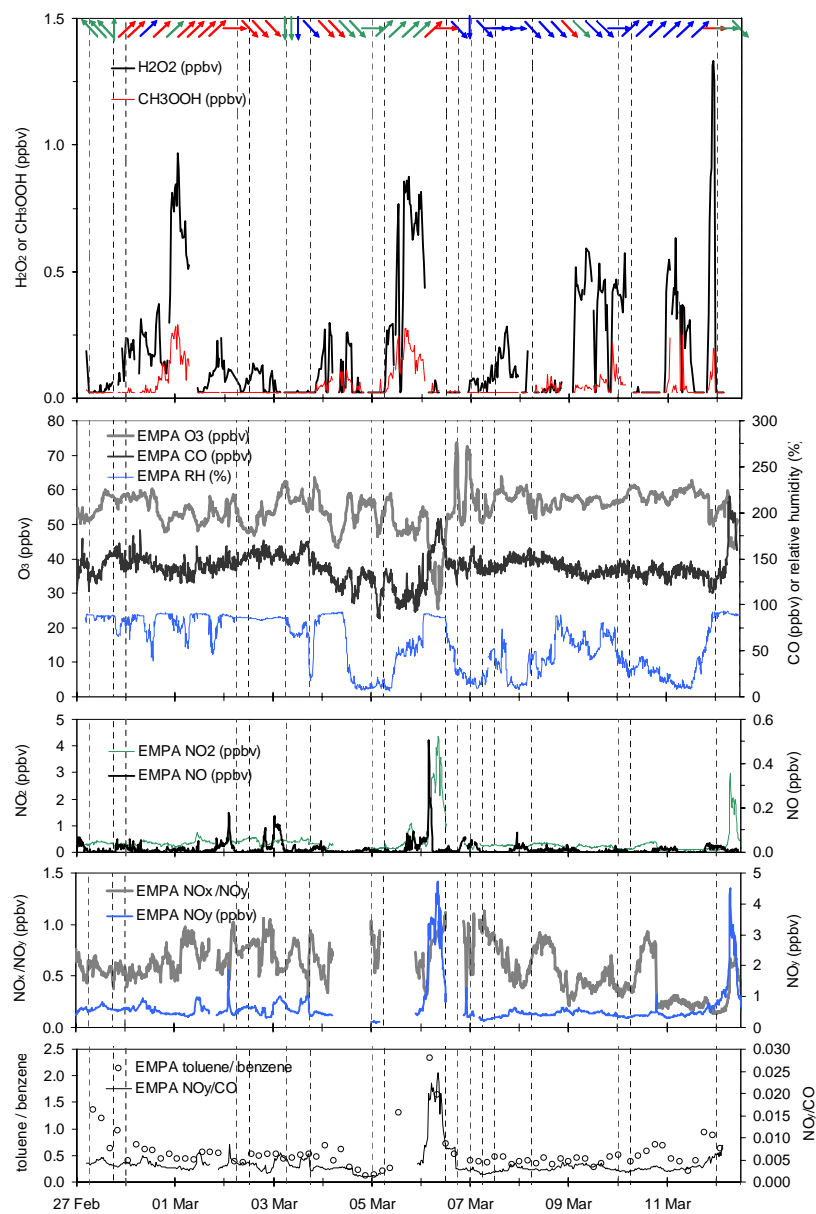

Fig. 4. Time series of $\mathrm{H}_{2} \mathrm{O}_{2}, \mathrm{CH}_{3} \mathrm{OOH}, \mathrm{O}_{3}, \mathrm{CO}$, relative humidity $(\mathrm{RH}), \mathrm{NO}_{2}, \mathrm{NO}, \mathrm{NO}_{\mathrm{y}}, \mathrm{NO}_{\mathrm{x}}$ to $\mathrm{NO}_{\mathrm{y}}$, toluene to benzene and $\mathrm{NO}_{\mathrm{y}}$ to $\mathrm{CO}$ ratios. Arrows in top panel and dashed vertical lines indicate changes in the prevailing wind direction deduced from the last day of 5-day back-trajectories (see Sect. 3.2 for further details). Descending air from $>3.6 \mathrm{~km}$ (blue arrows), ascending air from $<2 \mathrm{~km}$ (red arrows) and level (green arrows) indicates air that had remained at constant altitude for the last 5 days. Local NO and toluene contamination has been removed. Tick marks on time axis refer to noon (GMT).

Using these classifications, the high $\mathrm{NO}_{\mathrm{x}}$ levels during 6 March, which in combination with wet and dry deposition in the humid ascending air-mass was likely to have caused hydroperoxide concentrations to reduce (from their initial high values described in Sect. 3.4), can therefore be classed as fresh emissions $\left(\mathrm{NO}_{\mathrm{x}} / \mathrm{NO}_{\mathrm{y}} \sim 0.8\right)$ within a southwesterly, ascended air-mass (from $750-850 \mathrm{hPa}, \sim 2 \mathrm{~km}$ ). The toluene to benzene ratio increased from a background level (the campaign median of $\sim 0.5$ ) to values above 1.5 , which was also indicative of fresh emissions at this site ( $\mathrm{Li}$ et al., 2006a). The sources of these polluted south-westerly airmasses could be the industrialised region of the Valais Valley (southern Switzerland) or the Po Valley (northern Italy),

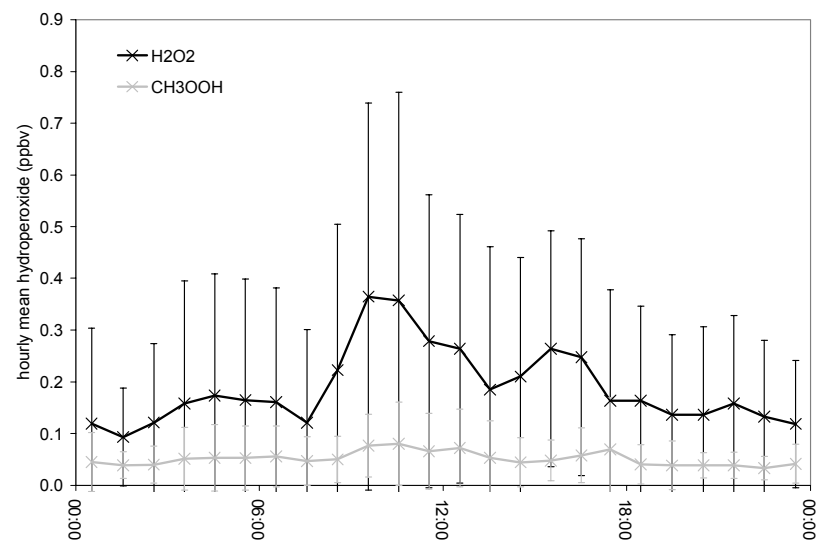

Fig. 5. Hourly averaged diurnal cycles for $\mathrm{H}_{2} \mathrm{O}_{2}$ (black crosses/line) and $\mathrm{CH}_{3} \mathrm{OOH}$ (grey crosses/line) where error bars show 1 standard deviation.

consistent with Seibert et al. (1998) and Forrer et al. (2000). The latter found that the highest $\mathrm{CO}$ (double the average value) and $\mathrm{NO}_{\mathrm{x}}(>1$ to $<10 \mathrm{ppbv}$ ) concentrations were associated with winds that transported anthropogenic pollution to this site from these industrialized regions of Switzerland and Italy. Similar conditions to those described by Forrer et al. (2000) occurred on 6 March when high concentrations of $\mathrm{CO}(>190 \mathrm{ppbv})$ and $\mathrm{NO}_{\mathrm{x}}(\sim 4 \mathrm{ppbv})$ were observed, due to upslope motion possibly associated with dynamical uplift from a frontal passage. Their paper described upslope motion associated with this south-westerly flow, as a process of transporting polluted air from lower altitudes to the site. The importance of these processes at this site was highlighted by Carpenter et al. (2000), who observed diurnal $\mathrm{CO}$ and $\mathrm{H}_{2} \mathrm{O}$ cycles indicative of daily upslope motion, and was developed further by Zellweger et al. (2003).

Thus much of the variability seen in the hydroperoxide concentrations observed can be attributed to changes in flow regime leading to changes in the levels of photo-pollutants rather than local changes in photolysis rates.

\subsection{Sampling of boundary layer and free tropospheric air}

Mountain sites such as JFJ are often thought to offer sampling within the free troposphere. In the previous section we have shown that there are examples of boundary layer air being sampled. Quantifying the fraction of boundary layer air sampled is important for placing the observations made at this site into a context, and is described e.g. in Zellweger et al. (2003).

The mean CO observed during the campaign was $140 \pm 14$ ppbv consistent with the seasonal cycle of CO previously measured at JFJ (Rinsland et al., 2000; Forrer et al., 2000; BUWAL, 2005). Carpenter et al. (2000) used the criteria of $\mathrm{CO}<200 \mathrm{ppbv}, \mathrm{NO}_{\mathrm{x}} / \mathrm{NO}_{\mathrm{y}}<0.3$, and a coarse screening of cloudy days, by excluding periods when global radiation 
was below the campaign median, to diagnose being within the free troposphere. Data collected as part of this campaign fulfilled these criteria for only $4 \%$ data coverage, which was lower than previous research of Carpenter et al. (2000) at this site, where free tropospheric air amounted to $17 \%$ using the same criteria during FREETEX 1998. The periods that satisfied the "free tropospheric" criteria of Carpenter et al. (2000) occurred for a short time on the 4, 6, 7, 9 and 10 March and for longer periods towards the end of the campaign (11 to 12 March). Some of these examples occurred during elevated hydroperoxide levels (i.e. 9, 10 and 11 to 12 March), which could be due to the reduction in deposition as a hydroperoxide sink. However, other factors must be affecting hydroperoxide concentrations in the air classified as "free tropospheric" during the 11 to 12 March, as there are short periods when the concentrations reduce to $<$ LoD.

Previous aircraft measurements of free tropospheric $\mathrm{H}_{2} \mathrm{O}_{2}$ have found a significant correlation between $\mathrm{H}_{2} \mathrm{O}_{2}$ and the product of its precursors, $\mathrm{O}_{3}$ and $\mathrm{H}_{2} \mathrm{O}$ (Penkett et al., 1995, 1998; Weinstein-Lloyd et al., 1998). The lack of a significant correlation $\left(\mathrm{R}^{2}<0.1\right)$ found from this dataset again implies that the simple free tropospheric assumptions made in these papers are not appropriate at this site (i.e. all three papers used altitudes $>1500 \mathrm{~m}$ and Weinstein-Lloyd et al. (1998) also used a coarse particle count of $<10 \mathrm{~cm}^{-3}$ to remove periods of cloud). If the criteria of Carpenter et al. (2000) is used to determine only those periods where air was sampled within the free troposphere, a weak positive correlation was then observed $\left(\mathrm{R}^{2} \sim 0.3\right)$.

Alongside the chemical criteria of Carpenter et al. (2000), relative humidity above $90 \%$ was also used to screen out cloudy days, rather than global radiation, which resulted in $18 \%$ of the data satisfying the "free tropospheric" definition. However, on examination of each 6-hourly trajectory release, only $28 \%$ entered the boundary layer (assumed to be $<1 \mathrm{~km}$, $\sim 900 \mathrm{hPa}$ ) during the previous 5 days. This implies that a much higher percentage of sampled air may have been of free tropospheric origin than was calculated based on the chemical tracers discussed above.

Various other subjective criteria, such as the $\mathrm{NO}_{\mathrm{y}} / \mathrm{CO}$ ratio, have also been utilised to define free tropospheric air. A $\mathrm{NO}_{\mathrm{y}} / \mathrm{CO}$ ratio of $\sim 0.005$ was used to indicate the upper troposphere (Jaegle et al., 1998), which is thought to account for both deposition and dilution effects (Zellweger et al., 2003). It was found that a large proportion of the data $(85 \%)$ was below this value, which implies that this criterion gives a similar result to that achieved by examining trajectories, in contrast to using the other chemical criteria discussed above. During previous campaigns at Jungfraujoch, the $\mathrm{NO}_{\mathrm{y}} / \mathrm{CO}$ ratio has been used to show that "free tropospheric" periods only made up 40\% during March to August 1997 and 1998 (Zellweger et al., 2003) and 57\% during 1993 to 1997 (Li et al., $2006^{1}$ ) of the measurement period.

\footnotetext{
${ }^{1}$ Li, Y., Staehelin, J., Auvray, M., Bey, I., and Schultz, M.:
}

There is therefore much uncertainty in establishing filtering criteria for free tropospheric air, as the chemistry and dynamics often disagree. This means that identifying the airmass origin through tracer concentrations and trajectories is difficult due to the lack of a definitive classification.

\subsection{Impact of high and low $\mathrm{NO}_{\mathrm{x}}$ on hydroperoxides}

As discussed in Sect. 3.2, there was some evidence that enhanced hydroperoxide concentrations were associated with south-westerly air, when $\mathrm{NO}_{\mathrm{x}}$ levels and depositional sinks were reduced. The three examples of south-westerly flow experienced during the campaign are described in Table 2, together with a fourth example of enhanced hydroperoxides in a north-westerly air-mass.

In the early morning of 6 March (Example A, Table 2), high levels of hydroperoxides $\left(\sim 0.9\right.$ and $\sim 0.3$ ppbv $\mathrm{H}_{2} \mathrm{O}_{2}$ and $\mathrm{CH}_{3} \mathrm{OOH}$ respectively) occurred in drier, south-westerly air that had remained at relatively constant altitude $(600-$ $700 \mathrm{hPa})$, with relatively low $\mathrm{CO}(\sim 110 \mathrm{ppbv})$ and $\mathrm{NO}_{\mathrm{x}}$ levels ( $\sim 0.3 \mathrm{ppbv})$, compared to the rest of the campaign. However, a spike in $\mathrm{NO}_{\mathrm{x}}$ of over $1 \mathrm{ppbv}$, at 07:00 caused a brief, partial reduction in hydroperoxides, due to suppression of $\mathrm{HO}_{2}$ by elevated $\mathrm{NO}_{\mathrm{x}}$. This air-mass displayed a moderate $\mathrm{NO}_{\mathrm{x}}$ to $\mathrm{NO}_{\mathrm{y}}$ ratio $(\sim 0.6)$, together with a relatively large increase in longer-lived alkanes compared to small increases in short-lived alkenes (see Whalley et al., 2004). These observations suggest slight photochemical aging and could be caused by some vertical mixing into the air-mass, by aged air from $\sim 650 \mathrm{hPa}(\sim 5 \mathrm{~km}), 5$ days earlier (see black and dark blue line, bottom left panel, in Fig. 2). The high levels of hydroperoxides in this event were therefore thought to be due to a combination of photochemically aged air with an abundance of $\mathrm{HO}_{\mathrm{x}}$, low $\mathrm{NO}_{\mathrm{x}}$, and little surface deposition, but ultimately it is difficult to decide upon what caused these hydroperoxide maxima.

In the afternoon of the 6 March (Example B, Table 2), freshly emitted $\mathrm{NO}_{\mathrm{x}}$ in a moist air-mass (relatively humidity $>80 \%$ ) arrived from the south-west and caused the suppression of hydroperoxides for over $10 \mathrm{~h}$. This increase in $\mathrm{NO}_{\mathrm{x}}$ was due to a shift to ascended air (from $750-850 \mathrm{hPa}$, see light blue and green lines, Fig. 2) that also exhibited enhanced CO (>150 ppbv). NO concentrations detected during this period were five times the level that Lee et al. (2000) ( $>100$ pptv) showed, which resulted in substantial suppression of hydroperoxide production alongside increased hydroperoxide deposition. Hydroperoxides were therefore reduced by a combination of high NO (average of 64 pptv) that competed with peroxy radical self-reactions, high $\mathrm{NO}_{2}$ (average of $2450 \mathrm{pptv}$ ) for several hours, providing a sink for $\mathrm{OH}$ (e.g. Poppe et al., 1993), wet deposition (see Sect. 3.5) and

Comparison between numerical simulations of two 3-D global models (GEOS-CHEM and MOZART) with ozone observations at Jungfraujoch (Switzerland) and ozone sondes from Payerne, Atmos. Environ., submitted, 2006. 
Table 2. Composition of air-masses with varying $\mathrm{NO}_{\mathrm{x}}$ to $\mathrm{NO}_{\mathrm{y}}$ ratios leading to hydroperoxide production and suppression.

\begin{tabular}{|c|c|c|c|c|}
\hline & $\begin{array}{l}\text { A) Semi-polluted, SW } \\
\text { air-mass }\end{array}$ & $\begin{array}{l}\text { B) Freshly polluted, } \\
\text { SW air-mass }\end{array}$ & $\begin{array}{l}\text { C) Photo- } \\
\text { chemically aged, } \\
\text { SW air-mass }\end{array}$ & $\begin{array}{l}\text { D) Photo- } \\
\text { chemically aged, } \\
\text { NW descending air }\end{array}$ \\
\hline $\begin{array}{l}\text { Air-mass } \\
\text { altitude origin } \\
\text { (Fig. } 2 \text { panel and, } \\
\text { trajectory colour) }\end{array}$ & $\begin{array}{l}\text { Remained at } \\
\sim 650 \mathrm{hPa} \text {, some } \\
\text { vertical mixing } \\
\text { with aged air from } \\
>5 \mathrm{~km} \text { (left panel, } \\
\text { black/dark blue) }\end{array}$ & $\begin{array}{l}\text { Ascended from } \\
\sim 800 \mathrm{hPa} \text { in last } \\
5 \mathrm{~d} \text { (left panel, } \\
\text { light blue/green) }\end{array}$ & $\begin{array}{l}\text { Descended from } \\
\sim 500 \mathrm{hPa} \text { in last } \\
5 \mathrm{~d} \text { (right panel, } \\
\text { dark/light blue) }\end{array}$ & $\begin{array}{l}\text { Descended from } \\
\sim 500 \mathrm{hPa} \text { in last } \\
5 \mathrm{~d} \text { (top panel, } \\
\text { green/orange) }\end{array}$ \\
\hline Time & 00:00 to 13:20 6 March & $13: 30$ to $23: 506$ March & $\begin{array}{l}\text { 07:00 } 11 \text { March to } \\
\text { 18:00 } 12 \text { March }\end{array}$ & $\begin{array}{l}\text { 14:00 } 9 \text { March to } 15: 20 \\
10 \text { March }\end{array}$ \\
\hline $\begin{array}{l}\text { Relative } \\
\text { humidity (\%) }\end{array}$ & $\sim 50$ & $>80$ & $<20$ & $30-80$ \\
\hline $\mathrm{O}_{3}$ (ppbv) & $45-55$ & $25-54$ & $49-63$ & $54-59$ \\
\hline $\mathrm{CO}$ (ppbv) & $92-160$ & 110-190 & $110-160$ & $120-150$ \\
\hline NO (pptv) & $<93$ & $<510$ & $<44$ & $<31$ \\
\hline $\mathrm{NO}_{\mathrm{x}}(\mathrm{ppbv})$ & $<0.46$ & $<2.3$ & $<0.12$ & $<0.20$ \\
\hline $\mathrm{NO}_{\mathrm{y}}(\mathrm{ppbv})$ & $<0.51$ & $<2.8$ & $<0.56$ & $<0.46$ \\
\hline $\mathrm{NO}_{\mathrm{x}} / \mathrm{NO}_{\mathrm{y}}$ & $\sim 0.60$ & $\sim 0.76$ & $\sim 0.22$ & $\sim 0.43$ \\
\hline $\mathrm{NO}_{\mathrm{y}} / \mathrm{CO}$ & $\sim 0.0044$ & $\sim 0.017$ & $\sim 0.0042$ & $\sim 0.0034$ \\
\hline toluene/benzene & $\sim 1.3$ & $\sim 2.0$ & $\sim 1.5$ & $\sim 0.42$ \\
\hline $\mathrm{H}_{2} \mathrm{O}_{2}$ (pptv) & $\leq 874$ & $<72$ & $\leq 1330$ & $\leq 592$ \\
\hline $\mathrm{CH}_{3} \mathrm{OOH}$ (pptv) & $\leq 276$ & $<60$ & $\leq 379$ & $\leq 215$ \\
\hline
\end{tabular}

contact with the surface, allowing increased dry deposition of $\mathrm{H}_{2} \mathrm{O}_{2}$.

During 11 to 12 March (Example C, Table 2), backtrajectories showed a south-westerly air-mass that had descended from $400-600 \mathrm{hPa}$ over 5 days, with little influence of air from lower altitudes (see blue lines in bottom right panel, Fig. 2). This very dry air $(\mathrm{RH}<20 \%)$ had a low $\mathrm{NO}_{\mathrm{x}} / \mathrm{NO}_{\mathrm{y}}$ ratio $(<0.3)$ and so can be considered as photochemically aged (Chin et al., 1994). To support this classification, 11 to 12 March also showed toluene/benzene ratios below 0.5 ( $\mathrm{Li}$ et al., 2005). Although CO remained around $140 \mathrm{ppbv}$, the relatively long lifetime of $\mathrm{CO}(\sim 60$ days) (Volz et al., 1981) compared to other photochemical tracers, means this air-mass could still have been of free tropospheric origin. This air-mass could therefore become rich in hydroperoxides because, little dry deposition could occur and there was a lack of $\mathrm{NO}_{\mathrm{x}}$ which prevented the competing reactions to $\mathrm{H}_{2} \mathrm{O}_{2}$ and $\mathrm{CH}_{3} \mathrm{OOH}$ production. The high concentrations of hydroperoxides imply that $\mathrm{HO}_{\mathrm{x}}$ was readily available.

During 9 to 10 March (Example D, Table 2), a descending north-westerly also gave observed hydroperoxide maxima alongside a $\mathrm{NO}_{\mathrm{x}}$ to $\mathrm{NO}_{\mathrm{y}}$ ratio of $\sim 0.4$. This aged airmass had descended from $\sim 500 \mathrm{hPa}$ for the previous 5 days (see green and orange lines, top panel, Fig. 2). Again a lack of $\mathrm{NO}_{\mathrm{x}}$ and dry deposition allowed hydroperoxides to accumulate, but these peaks are lower in concentration than for other examples (1, 6 and 11 to 12 March) that arrived in south-westerly air, which lends support to the findings that more $\mathrm{HO}_{\mathrm{x}}$ was available in south-westerly air-masses, which have been subjected to more intense sunlight, water vapour concentrations and so have enhanced radical concentrations.

Overall we find that oxides of nitrogen have a significant impact on the concentrations of hydroperoxides. Air coming from the south-west with moderate levels of $\mathrm{NO}_{\mathrm{x}}$ displays higher hydroperoxide concentration than air which is more significantly polluted, or air coming from the north. This is due to a combination of a history of higher photolysis rates and water vapour concentration, leading to enhanced $\mathrm{HO}_{\mathrm{x}}$ production in south-westerly air, with also reduced $\mathrm{HO}_{\mathrm{x}}$ loss and lower $\mathrm{OH}$ to $\mathrm{HO}_{2}$ ratios due to the moderate $\mathrm{NO}_{\mathrm{x}}$ concentrations.

\subsection{Wet deposition and cloud processing}

Unlike the case on the 6 March, the decrease in hydroperoxide concentration observed on the 1 March was not due to a combination of deposition and an increase in $\mathrm{NO}_{\mathrm{x}}$. The trajectories showed a change to an ascending air-mass, associated with an increase in relative humidity $(>90 \%)$ and increased deposition, but no increases in $\mathrm{NO}_{\mathrm{x}}$ were observed. Dilution effects with an air-mass that had been exposed to increased dry deposition to the surface could therefore have 
been partly responsible for the observed reduction in hydroperoxides. The high humidity indicates that cloud processing had also occurred. Previous studies have shown that air-masses exposed to cloud processing exhibit lower concentrations of $\mathrm{H}_{2} \mathrm{O}_{2}$ due to wet deposition (e.g. Heikes et al., 1987; Chandler et al., 1988; Gallagher et al., 1991). It appears that $\mathrm{H}_{2} \mathrm{O}_{2}$ concentrations during this event reduced faster than $\mathrm{CH}_{3} \mathrm{OOH}$ due to its much higher solubility (the ratio of Henry's Law coefficients $\left(\mathrm{H}_{\mathrm{H}_{2} \mathrm{O}_{2}} / \mathrm{H}_{\left.\mathrm{CH}_{3} \mathrm{OOH} \sim 260\right)}\right.$ but because of the data gap during this hydroperoxide reduction, the role of uptake into water droplets and dilution by changing air-masses is unclear.

\subsection{Agreement with a previous photochemical box model}

Zanis et al. (1999) described constrained box modelling work of the radicals at the JFJ site during April to May 1996. However, at the time of their study, observations of hydroperoxides were not available to help constrain their modelling effort. Their work simulated $\mathrm{H}_{2} \mathrm{O}_{2}$ concentrations in the order of a magnitude, from 1700 to $170 \mathrm{pptv}$ without and including dry deposition respectively. The mean observed $\mathrm{H}_{2} \mathrm{O}_{2}$ concentrations of $183 \pm 233$ pptv during this campaign are thus much more consistent with the calculations that include a surface depositional sink. However, there was some indication of air-masses that were representative of less disturbed free tropospheric air (e.g. case C, Table 2), where the $\mathrm{H}_{2} \mathrm{O}_{2}$ concentration $(\leq 1330 \mathrm{pptv})$ was closer to the upper estimate of the box model, detailed in Zanis et al. (1999). Meteorological conditions during the 1996 campaign were comparable to our campaign in 2003, with similar temperature, pressure and wind speeds, and consistent concentrations of $\mathrm{O}_{3}$ and water vapour. The main differences between the two campaigns were the lower $\mathrm{CO}, j\left(\mathrm{O}^{1} D\right)$ and $\mathrm{NO}$ measured in 2003 compared to 1996. The variations in the concentrations of photochemical pre-cursors to $\mathrm{H}_{2} \mathrm{O}_{2}$ between the two campaigns alone, is not sufficient to account for an order of a magnitude difference between the previously modelled concentration of $\mathrm{H}_{2} \mathrm{O}_{2}$ without a depositional sink and our mean observations of $\mathrm{H}_{2} \mathrm{O}_{2}$. We conclude that depositional processes are important at this site for determining hydroperoxide concentration during periods influenced by the boundary layer.

Mean NO levels during this 2003 campaign were low ( $\sim 19$ pptv), which places the site during the observation period slightly below the NO regime (20 to $100 \mathrm{pptv}$ ) set by Zanis et al. (1999) for simultaneous $\mathrm{O}_{3}$ and $\mathrm{H}_{2} \mathrm{O}_{2}$ production. $\mathrm{H}_{2} \mathrm{O}_{2}$ can be produced alongside $\mathrm{O}_{3}$ in this regime because there is sufficient $\mathrm{NO}$ to lead to $\mathrm{O}_{3}$ production, but peroxy radical combination reactions are still able to dominate over the loss of $\mathrm{OH}$ through $\mathrm{NO}_{2}$. During the campaign, the data selected using the criteria of Carpenter et al. (2000) for free tropospheric air, also did not display a significant anticorrelation between $\mathrm{O}_{3}$ and $\mathrm{H}_{2} \mathrm{O}_{2}\left(\mathrm{R}^{2}=0.2\right)$. This is consistent with simultaneous production of both $\mathrm{O}_{3}$ and $\mathrm{H}_{2} \mathrm{O}_{2}$ but is in contrast to the previously observed anti-correlation between $\mathrm{O}_{3}$ and $\mathrm{H}_{2} \mathrm{O}_{2}$ for the remote marine boundary layer (e.g. Ayers et al., 1992). Again this observational evidence lends further support to the case that the JFJ station mainly sampled boundary layer air during this campaign. However, the lack of anti-correlation between $\mathrm{O}_{3}$ and $\mathrm{H}_{2} \mathrm{O}_{2}$ could also be attributed to other factors such as the difference in lifetime between the two species, or the possibility that $\mathrm{NO}_{\mathrm{x}}$ could be mixed out of the boundary layer (e.g. via convection or frontal systems) so that when free tropospheric air is sampled at JFJ, it may contain sufficient $\mathrm{NO}$ in it for $\mathrm{O}_{3}$ production to occur.

The box modelling described by Zanis et al. (1999) is consistent with the hydroperoxide observations made during this study. During periods where there was indication of boundary layer influence, agreement required a depositional sink. Thus even at this high altitude mountain site, the impact of the boundary layer cannot be ignored and as a consequence, filtering and data flagging of air disturbed by the surface is essential.

\subsection{Other hydroperoxides}

The oxidation of hydrocarbons within the atmosphere should lead to the production of a large number of hydroperoxides. Previous observations have detected hydroxymethyl hydroperoxide $\left(\mathrm{HOCH}_{2} \mathrm{OOH}\right)$, peroxyacetic acid $\left(\mathrm{CH}_{3} \mathrm{C}(\mathrm{O}) \mathrm{OOH}\right)$, and ethylhydroperoxide $\left(\mathrm{C}_{2} \mathrm{H}_{5} \mathrm{OOH}\right)$ at this altitude (Fels and Junkermann, 1994; Weinstein-Lloyd et al., 1998; Crounse et al., 2005, private communication). However, they were not observed during this study. This is surprising given that two of these species have higher solubility than $\mathrm{H}_{2} \mathrm{O}_{2}$ and $\mathrm{CH}_{3} \mathrm{OOH}$ respectively $\left(\mathrm{H}_{\mathrm{HOCH}_{2} \mathrm{OOH}}=1.7 \times 10^{6} \mathrm{M} \mathrm{atm}^{-1}\right.$, Sander et al., 2003, and $\mathrm{H}_{\mathrm{CH}_{3} \mathrm{C}(\mathrm{O}) \mathrm{OOH}}=473 \mathrm{M} \mathrm{atm}^{-1}$, Seinfeld and Pandis, 1998), which should permit more efficient collection via this technique (giving $\sim 94$ and $\sim 43 \%$ respectively based on the sampler collection efficiency and the Henry's Law Constant for these compounds). Using these collection efficiencies and the limit of detection for the instrumental set-up, an upper limit of $\sim 22$ and $\sim 48$ pptv can therefore be stated for $\mathrm{HOCH}_{2} \mathrm{OOH}$ and $\mathrm{CH}_{3} \mathrm{C}(\mathrm{O}) \mathrm{OOH}$ respectively. The collection efficiency is expected to be low $(<40 \%)$ for hydroperoxides less soluble than $\mathrm{CH}_{3} \mathrm{OOH}$, such as $\mathrm{C}_{2} \mathrm{H}_{5} \mathrm{OOH}$, meaning that concentrations must be above 50 pptv to be sampled successfully.

Fels and Junkermann (1994) observed levels of $\mathrm{HOCH}_{2} \mathrm{OOH}$ up to $550 \mathrm{pptv}$ at a mountainous alpine site $\left(1780 \mathrm{~m}\right.$ a.m.s.l.), and reported that $\mathrm{CH}_{3} \mathrm{OOH}$ and $\mathrm{HOCH}_{2} \mathrm{OOH}$ were the dominant $\mathrm{ROOH}$, with $\mathrm{C}_{2} \mathrm{H}_{5} \mathrm{OOH}$ and $\mathrm{CH}_{3} \mathrm{C}(\mathrm{O}) \mathrm{OOH}$ contributing $<10 \%$. However, their research was conducted during summer, and at lower altitude, where sources of ROOH are more abundant. In comparison, the JFJ measurements were made during early spring when concentrations would be expected to be lower. A more recent 
study by Valverde-Canossa et al. (2005) inferred ROOH concentrations from aqueous-phase cloud water samples at a mountainous site in Germany $(937 \mathrm{~m}$ a.m.s.l.) with $\mathrm{CH}_{3} \mathrm{OOH}, \mathrm{HOCH}_{2} \mathrm{OOH}$ and 1-hydroxyethyl hydroperoxide $\left(\mathrm{CH}_{3} \mathrm{CH}(\mathrm{OH}) \mathrm{OOH}\right)$ concentrations of $<40,<0.020$ and $<3.5$ pptv respectively. These levels of $\mathrm{ROOH}$ were below the detection limit of the analytical instrument used at JFJ.

Significant levels of $\mathrm{CH}_{3} \mathrm{C}(\mathrm{O}) \mathrm{OOH}$ (100-300 pptv) were observed in the recent INTEX-NA aircraft campaign at the same altitude as JFJ over the Atlantic coast of USA (Crounse et al., 2005, private communication). Observations of $\mathrm{H}_{2} \mathrm{O}_{2}$ during the INTEX-NA campaign were a factor of as much as 10 higher than were observed during this JFJ campaign. Thus if the $\mathrm{CH}_{3} \mathrm{C}(\mathrm{O}) \mathrm{OOH}$ concentrations scales with $\mathrm{H}_{2} \mathrm{O}_{2}$ concentrations, we would expect concentrations of $\mathrm{CH}_{3} \mathrm{C}(\mathrm{O}) \mathrm{OOH}$ of around 10 to $30 \mathrm{pptv}$, which is below the detection limit and thus would not be detected with this instrument. It seems likely that other hydroperoxides are present in the atmosphere at JFJ. However, their expected concentrations are likely to be below those that can be observed by the current instrumental set-up.

\section{Conclusions}

Gas-phase hydroperoxide measurements were made at Jungfraujoch High Altitude Research Station as part of the FREETEX campaign during February and March 2003. These are the first speciated hydroperoxide measurements for this site, providing a quantitative assessment of both inorganic and organic hydroperoxide concentrations. $\mathrm{H}_{2} \mathrm{O}_{2}$ and $\mathrm{CH}_{3} \mathrm{OOH}$ were detected but no other hydroperoxides were detected, consistent with our understanding of their concentrations within the atmosphere. Although a diurnal cycle in both $\mathrm{H}_{2} \mathrm{O}_{2}$ and $\mathrm{CH}_{3} \mathrm{OOH}$ was observed, it was not strong because of meteorologically-driven variability. There was some indication that air-masses from the south-west displayed higher hydroperoxide concentrations, possibly caused by enhanced photochemistry, but ultimately, it was difficult to decide upon what caused hydroperoxide maxima during the campaign. Air-masses which had been exposed to high levels of recent pollution showed lower concentrations of hydroperoxides, indicative of the suppression of $\mathrm{HO}_{2}$ by $\mathrm{NO}_{\mathrm{x}}$. The concentrations of hydroperoxide measured during the campaign were consistent with previous box-modelling work for the site. This only included periods when the site was influenced by the boundary layer if a depositional sink was included in the box model. Thus comparisons between these observations and the results of chemical transport models should be carried out carefully during periods where there was indication that boundary layer air was sampled.

Acknowledgements. The authors would like to thank the International Foundation Jungfraujoch and Gornergrat and the custodians at the Jungfraujoch Research Station for their assistance and hospitality. Parts of the measurements were made by the Swiss National
Air Pollution Monitoring Network (NABEL) on behalf of the Swiss Federal Office for the Environment (FOEN). The financial support of the NABEL network by FOEN is acknowledged. S. J. Walker would like to thank R. Purvis (now at FAAM, UK), J. Lee (now at University of York, UK) and L. Whalley (University of Leeds, UK) for their generosity and support throughout the campaign. The authors would also like to acknowledge R. Morgan (for his assistance in preparing for the campaign) and S. Arnold (for assistance in the preparation of back-trajectory plots). S. J. Walker acknowledges a NERC studentship (NER/S/S/2002/11165) and A. V. Jackson acknowledges the NERC/AFI grant (RG.ENVI.444968).

Edited by: P. Monks

\section{References}

Ayers, G. P., Penkett, S. A., Gillett, R. W., Bandy, B., Galbally, I. E., Meyer, C. P., Elsworth, C. M., Bentley, S. T., and Forgan, B. W.: Evidence for Photochemical Control of Ozone Concentrations in Unpolluted Marine Air, Nature, 360, 446-449, 1992.

Baltensperger, U., Gaggeler, H. W., Jost, D. T., Lugauer, M., Schwikowski, M., Weingartner, E., and Seibert, P.: Aerosol climatology at the high-alpine site Jungfraujoch, Switzerland, J. Geophys. Res.-Atmos., 102, 19707-19715, 1997.

BUWAL (Bundesamt für Umwelt, Wald und Landschaft - Swiss Federal Office for Environment, Forest and Landscape): Swiss National Air Pollution Monitoring Network (NABEL), Annual Report 2004, Series of Publications on the Environment (Schriftenreihe Umwelt), 388, 91-96, 2005.

Carpenter, L. J., Green, T. J., Mills, G. P., Bauguitte, S., Penkett, S. A., Zanis, P., Schuepbach, E., Schmidbauer, N., Monks, P. S., and Zellweger, C.: Oxidized nitrogen and ozone production efficiencies in the springtime free troposphere over the Alps, J. Geophys. Res.-Atmos., 105, 14 547-14 559, 2000.

Chandler, A. S., Choularton, T. W., Dollard, G. J., Eggleton, A. E. J., Gay, M. J., Hill, T. A., Jones, B. M. R., Tyler, B. J., Bandy, B. J., and Penkett, S. A.: Measurements of $\mathrm{H}_{2} \mathrm{O}_{2}$ and $\mathrm{SO}_{2}$ in clouds and estimates of their reaction rate, Nature, 336, 562-565, 1988.

Chin, M., Jacob, D. J., Munger, J. W., Parrish, D. D., and Doddridge, B. G.: Relationship of ozone and carbon monoxide over North America, J. Geophys. Res.-Atmos., 99, 14 565-14 573, 1994.

Cofer, W. R., Collins, V. G., and Talbot, R. W.: Improved Aqueous Scrubber for Collection of Soluble Atmospheric Trace Gases, Environ. Sci. Technol., 19, 557-560, 1985.

Cohan, D. S., Schultz, M. G., Jacob, D. J., Heikes, B. G., and Blake, D. R.: Convective injection and photochemical decay of peroxides in the tropical upper troposphere: Methyl iodide as a tracer of marine convection, J. Geophys. Res.-Atmos., 104, 5717-5724, 1999.

Crutzen, P. J. and Zimmermann, P. H.: The Changing Photochemistry of the Troposphere, Tellus, Series A-Dynamic Meteorology and Oceanography, 43, 136-151, 1991.

Dommen, J., Neftel, A., Sigg, A., and Jacob, D. J.: Ozone and Hydrogen-Peroxide During Summer Smog Episodes over the Swiss Plateau - Measurements and Model Simulations, J. Geophys. Res.-Atmos., 100, 8953-8966, 1995.

ECMWF: The description of the ECMWF/WRCP Level III-A global atmospheric data archive, Reading, 1995. 
Fels, M. and Junkermann, W.: The Occurrence of Organic Peroxides in Air at a Mountain Site, Geophys. Res. Lett., 21, 341-344, 1994.

Finlayson-Pitts, B. J. and Pitts-Jr, J. N.: Atmospheric Chemistry: Fundamentals and Experimental Techniques, Wiley Interscience, John Wiley and Sons, New York, 1986.

Forrer, J., Ruttimann, R., Schneiter, D., Fischer, A., Buchmann, B., and Hofer, P.: Variability of trace gases at the high-Alpine site Jungfraujoch caused by meteorological transport processes, J. Geophys. Res.-Atmos., 105, 12 241-12 251, 2000.

Gallagher, M. W., Choularton, T. W., Downer, R., Tyler, B. J., Stromberg, I. M., Mill, C. S., Penkett, S. A., Bandy, B., Dollard, G. J., Davies, T. J., and Jones, B. M. R.: Measurement of the entrainment of hydrogen peroxide into cloud systems, Atmos. Environ., Part A - General Topics, 25(9), 2029-2038, 1991.

Heikes, B. G., Kok, G. L., Walega, J. G., and Lazrus, A. L.: $\mathrm{H}_{2} \mathrm{O}_{2}$, $\mathrm{O}_{3}$ and $\mathrm{SO}_{2}$ Measurements in the Lower Troposphere over the Eastern United States During Fall, J. Geophy. Res.-Atmos., 92, 915-931, 1987.

Heikes, B. G., Lee, M., Bradshaw, J., Sandholm, S., Davis, D. D., Crawford, J., Rodriguez, J., Liu, S., McKeen, S., Thornton, D., Bandy, A., Gregory, G., Talbot, R., and Blake, D.: Hydrogen peroxide and methylhydroperoxide distributions related to ozone and odd hydrogen over the North Pacific in the fall of 1991, J. Geophys. Res.-Atmos., 101, 1891-1905, 1996a.

Heikes, B. G., Lee, M. H., Jacob, D. J., Talbot, R., Bradshaw, J., Singh, H., Blake, D., Anderson, B., Fuelberg, H., and Thompson, A. M.: Ozone, hydroperoxides, oxides of nitrogen, and hydrocarbon budgets in the marine boundary layer over the South Atlantic, J. Geophys. Res.-Atmos., 101, 24 221-24 234, 1996 b.

Jackson, A. V. and Hewitt, C. N.: Hydrogen peroxide and organic hydroperoxide concentrations in air in a eucalyptus forest in central Portugal, Atmos. Environ., 30, 819-830, 1996.

Jaegle, L., Jacob, D. J., Wang, Y., Weinheimer, A. J., Ridley, B. A., Campos, T. L., Sachse, G. W., and Hagen, D. E.: Sources and chemistry of $\mathrm{NO}_{\mathrm{x}}$ in the upper troposphere over the United States, Geophys. Res. Lett., 25, 1705-1708, 1998.

Kleinman, L. I.: Photochemical formation of peroxides in the boundary layer, J. Geophys. Res.-Atmos., 91, 889-904, 1986.

Lazrus, A. L., Kok, G. L., Gitlin, S. N., Lind, J. A., and McLaren, S. E.: Automated Fluorometric Method for Hydrogen-Peroxide in Atmospheric Precipitation, Anal. Chem., 57, 917-922, 1985.

Lazrus, A. L., Kok, G. L., Lind, J. A., Gitlin, S. N., Heikes, B. G., and Shetter, R. E.: Automated Fluorometric Method for Hydrogen-Peroxide in Air, Anal. Chem., 58, 594-597, 1986.

Lee, M. H., Heikes, B. G., and O'Sullivan, D. W.: Hydrogen peroxide and organic hydroperoxide in the troposphere: A review, Atmos. Environ., 34, 3475-3494, 2000.

Lehmann, M., Sigg, A., Lehmann, B. E., and Neftel, A.: $\mathrm{H}_{2} \mathrm{O}_{2}$ concentration during summer smog situations at the high Alpine research station Jungfraujoch, Air Poll. Res. Rept., 39. Brussels, Comm. European Commun., 1992.

Li, Y. S., Campana, M., Reimann, S., Schaub, D., Stemmler, K., Staehelin, J., and Peter, T.: Hydrocarbon concentrations at the Alpine mountain sites Jungfraujoch and Arosa, Atmos. Environ., 39, 1113-1127, 2005.

Lightfoot, P. D., Cox, R. A., Crowley, J. N., Destriau, M., Hayman, G. D., Jenkin, M. E., Moortgat, G. K., and Zabel, F.: Organic Peroxy Radicals - Kinetics, Spectroscopy and Tropospheric Chem- istry, Atmos. Environ., Part A - General Topics, 26, 1805-1961, 1992.

Lugauer, M., Baltensperger, U., Furger, M., Gaggeler, H. W., Jost, D. T., Schwikowski, M., and Wanner, H.: Aerosol transport to the high Alpine sites Jungfraujoch (3454 m a.s.1.) and Colle Gnifetti (4452 m asl), Tellus, Ser. B-Chem. Phys. Meteorol., 50, 76-92, 1998.

Morgan, R. B.: Field Studies of Atmospheric Peroxides and the Development of Sampling Methods, School of the Environment, University of Leeds, pp. 191, 2004.

Morgan, R. B. and Jackson, A. V.: Measurements of gas-phase hydrogen peroxide and methyl hydroperoxide in the coastal environment during the PARFORCE project, J. Geophys. Res.Atmos., 107, 8109, doi:10.1029/2000JD000257 2002.

Penkett, S. A., Bandy, B. J., Reeves, C. E., McKenna, D., and Hignett, P.: Measurements of peroxides in the atmosphere and their relevance to the understanding of global tropospheric chemistry, Faraday Discuss., 155-174, 1995.

Penkett, S. A., Jones, B. M. R., Brice, K. A., and Eggleton, A. E. J.: Importance of atmospheric ozone and hydrogen peroxide in oxidizing sulphur dioxide in cloud and rainwater, Atmos. Environ., 13, 123-137, 1979.

Penkett, S. A., Reeves, C. E., Bandy, B. J., Kent, J. M., and Richer, H. R.: Comparison of calculated and measured peroxide data collected in marine air to investigate prominent features of the annual cycle of ozone in the troposphere, J. Geophys. Res.-Atmos., 103, 13 377-13 388, 1998.

Poppe, D., Wallasch, M., and Zimmermann, J.: The dependence of the concentration of $\mathrm{OH}$ on its precursors under moderately polluted conditions - a model study, J. Atmos. Chem., 16, 6178, 1993.

Ravetta, F., Jacob, D. J., Brune, W. H., Heikes, B. G., Anderson, B. E., Blake, D. R., Gregory, G. L., Sachse, G. W., Sandholm, S. T., Shetter, R. E., Singh, H. B., and Talbot, R. W.: Experimental evidence for the importance of convected methylhydroperoxide as a source of hydrogen oxide $\left(\mathrm{HO}_{\mathrm{x}}\right)$ radicals in the tropical upper troposphere, J. Geophys. Res.-Atmos., 106, 32 709-32 716, 2001.

Ray, J. D., van Valin, C. C., and Boatman, J. F.: The Vertical Distribution of Atmospheric $\mathrm{H}_{2} \mathrm{O}_{2}-$ a Case Study, J. Geophys. Res.Atmos., 97, 2507-2517, 1992.

Reeves, C. E. and Penkett, S. A.: Measurements of peroxides and what they tell us, Chem. Rev., 103, 5199-5218, 2003.

Reimann, S., Schaub, D., Stemmler, K., Folini, D., Hill, M., Hofer, P., Buchmann, B., Simmonds, P. G., Greally, B. R., and O'Doherty, S.: Halogenated greenhouse gases at the Swiss high Alpine site of Jungfraujoch ( $3580 \mathrm{~m}$ a.s.1.): continuous measurements and their use for regional European source allocation, J. Geophys. Res.-Atmos., 109, D05307, doi:10.1029/2003JD003923, 2004.

Rinsland, C. P., Mahieu, E., Zander, R., Demoulin, P., Forrer, J., and Buchmann, B.: Free tropospheric $\mathrm{CO}, \mathrm{C}_{2} \mathrm{H}_{6}$, and $\mathrm{HCN}$ above central Europe: recent measurements from the Jungfraujoch station including the detection of elevated columns during 1998, J. Geophys. Res.-Atmos., 105, 24 235-24 249, 2000.

Sander, S. P., Friedl, R. R., Ravishankara, A. R., Golden, D. M., Kolb, C. E., Kurylo, M. J., Huie, R. E., Orkin, V. L., Molina, M. J., Moortgat, G. K., and Finlayson-Pitts, B. J.: Chemical Kinetics and Photochemical Data for Use in Atmospheric Studies, JPL 
Publication 02-25, Evaluation No. 14, 5-35, 2003.

Seibert, P., Kromp-Kolb, H., Kasper, A., Kalina, M., Puxbaum, H., Jost, D. T., Schwikowski, M., and Baltensperger, U.: Transport of polluted boundary layer air from the Po Valley to high-alpine sites, Atmos. Environ., 32, 3953-3965, 1998.

Seinfeld, J. H. and Pandis, S. N.: Atmospheric Chemistry and Physics: from Air Pollution to Climate Change, John Wiley \& Sons Inc., 1998.

Sigg, A., Lehmann, B. E., Lehmann, M., and Neftel, A.: $\mathrm{H}_{2} \mathrm{O}_{2}$ measurements in the boundary layer over Switzerland during summer smog episodes, Air Poll. Res. Rept., 39. Brussels, Comm. European Commun., 1992.

Taylor, J. K.: Quality Assurance of Chemical Measurements, Chelsea, MI, Lewis, 1987.

Tremmel, H. G., Junkermann, W., and Slemr, F.: On the distribution of hydrogen peroxide in the lower troposphere over the northeastern United States during late summer 1988, J. Geophys. Res.Atmos., 98, 1083-1099, 1993.

Valverde-Canossa, J., Wieprecht, W., Acker, K., and Moortgat, G. $\mathrm{K}$.: $\mathrm{H}_{2} \mathrm{O}_{2}$ and organic peroxide measurements in an orographic cloud: The FEBUKO experiment, Atmos. Environ., 39, 42794290, 2005.

Volz, A., Ehhalt, D. H., and Derwent, R. G.: Seasonal and Latitudinal Variation of (CO)-C-14 and Tropospheric Concentration of OH Radicals, J. Geophys. Res.-Oceans Atmos., 86, 5163-5171, 1981.

Watanabe, K., Ishizaka, Y., and Tanaka, H.: Measurements of atmospheric peroxides concentrations near the summit of Mt Norikura in Japan, J. Meteorol. Soc. of Japan, 73, 1153-1160, 1995.

Weinstein-Lloyd, J. B., Lee, J. H., Daum, P. H., Kleinman, L. I., Nunnermacker, L. J., and Springston, S. R.: Measurements of peroxides and related species during the 1995 summer intensive of the Southern Oxidants Study in Nashville, Tennessee, J. Geophys. Res.-Atmos., 103, 22 361-22 373, 1998.
Whalley, L. K., Lewis, A. C., McQuaid, J. B., Purvis, R. M., Lee, J. D., Stemmler, K., Zellweger, C., and Ridgeon, P.: Two highspeed, portable GC systems designed for the measurement of non-methane hydrocarbons and PAN: Results from the Jungfraujoch High Altitude Observatory, J. Environ. Monit., 6, 234-241, 2004.

Zanis, P., Monks, P. S., Green, T. J., Schuepbach, E., Carpenter, L. J., Mills, G. P., Rickard, A. R., Brough, N., and Penkett, S. A.: Seasonal variation of peroxy radicals in the lower free troposphere based on observations from the FREE Tropospheric EXperiments in the Swiss Alps, Geophys. Res. Lett., 30, 1497, doi:10.1029/2003GL017122, 2003.

Zanis, P., Monks, P. S., Schuepbach, E., Carpenter, L. J., Green, T. J., Mills, G. P., Bauguitte, S., and Penkett, S. A.: In situ ozone production under free tropospheric conditions during FREETEX '98 in the Swiss Alps, J. Geophys. Res.-Atmos., 105, 24223 24234,2000 a.

Zanis, P., Monks, P. S., Schuepbach, E., and Penkett, S. A.: The role of in situ photochemistry in the control of ozone during spring at the Jungfraujoch (3580 m a.s.1.) - comparison of model results with measurements, J. Atmos. Chem., 37, 1-27, 2000 b.

Zanis, P., Monks, P. S., Schuepbach, E., and Penkett, S. A.: On the relationship of $\mathrm{HO}_{2}+\mathrm{RO}_{2}$ with $\mathrm{j}((\mathrm{OD})-\mathrm{D}-1)$ during the Free Tropospheric Experiment (FREETEX '96) at the Jungfraujoch Observatory (3580 m above sea level) in the Swiss Alps, J. Geophy. Res.-Atmos., 104, 26913-26 925, 1999.

Zellweger, C., Ammann, M., Buchmann, B., Hofer, P., Lugauer, M., Ruttimann, R., Streit, N., Weingartner, E., and Baltensperger, U.: Summertime $\mathrm{NO}_{y}$ speciation at the Jungfraujoch, $3580 \mathrm{~m}$ above sea level, Switzerland, J. Geophys. Res.-Atmos., 105, 66556667, 2000.

Zellweger, C., Forrer, J., Hofer, P., Nyeki, S., Schwarzenbach, B., Weingartner, E., Ammann, M., and Baltensperger, U.: Partitioning of reactive nitrogen $\left(\mathrm{NO}_{\mathrm{y}}\right)$ and dependence on meteorological conditions in the lower free troposphere, Atmos. Chem. Phys., 3, 779-796, 2003, http://www.atmos-chem-phys.net/3/779/2003/. 